\title{
Exploitation of siderophore producing bacteria Acinetobacter soli (MTCC-5918) for lipids and reactive oxygen species in Chlorella variabilis (ATCC- PTA 12198) through co-cultivation
}

Soundarya Rajapitamahuni

Central Salt and Marine Chemicals Research Institute CSIR

Pooja Bachani

Central Salt and Marine Chemicals Research Institute CSIR

Vamsi Bharadwaj

Central Salt and Marine Chemicals Research Institute CSIR

Sandhya Mishra ( $\nabla$ smishra@csmcri.res.in )

Central Salt and Marine Chemicals Research Institute CSIR https://orcid.org/0000-0002-2412-4927

\section{Research}

Keywords: Microalgae, Bacteria, Siderophores, Co-culture, Lipids, Oxidative stress

Posted Date: May 3rd, 2020

DOI: https://doi.org/10.21203/rs.3.rs-25343/v1

License: (c) (1) This work is licensed under a Creative Commons Attribution 4.0 International License.

Read Full License 


\section{Abstract \\ Background}

Increased iron uptake via siderophores triggers a series of physiological processes and generation of reactive oxygen species (ROS) which causes damage to proteins, lipids, carbohydrates, resulting into micro algal cell lysis. Moreover, there are reports mentioning oxidative stress is a mediator for increased lipid accumulation in microalgae. The main aim of this study is co-cultivation of the bacteria Acinetobacter soli (MTCC- 5918) and the microalgae Chlorella variabilis (ATCC-PTA 12198) under iron limiting conditions and the threshold value of iron that trigger oxidizing stress to microalgae. Further, the ROS generation in the microalgae $C$. variabilis was determined in terms of $\mathrm{OH}, \mathrm{SO}_{2}$ and $\mathrm{H}_{2} \mathrm{O}_{2}$ concentration in the cells while co-cultivation.

\section{Results}

The co-cultured biomass contains $(45.92 \pm 0.74 \%)$ lipid content which was about $21 \%$ higher than that of the axenically grown microalgae. Carbohydrate content also increased to $40 \%$ than that of the control culture. Oxidative stress is a mediator for increased lipid accumulation in microalgae. As growth inhibition triggered due to the generation of high ROS toxicity during iron deficiency an increase in concentration of $\mathrm{OH}$ and $\mathrm{H}_{2} \mathrm{O}_{2}$ content was observed. In iron sufficient medium ash content of cocultivated microalgae showed $32 \%$ and in iron deficient medium showed $14.23 \%$ which shows $44 \%$ decrease of ash content. Our novel approach significantly outperforms the involvement of different reactive oxygen species (ROS) in induction and in regulation of chelator release from cells at adequate $\mathrm{Fe}$ supply, which is also affecting the growth,lipids, carbohydrates, proteins, pigments, etc.

\section{Conclusions}

The findings of the present study highlights that oxidative stress is a mediator for increased lipid accumulation in microalgae that simultaneously becomes an alternative strategy for the improvement of biofuel potential in $C$. variabilis. The study portraysthe significance of co-cultivation of $A$. soli and $C$. variabilis induced oxidative stress (ROS generation) in microalgae caused due to higher uptake of iron via siderophore

\section{Background}

Iron is an essential element for all microorganisms as it is involved in multiple metabolic processes like respiration (contains ferredoxins, heme containing cytochromes) and key enzymatic reactions [1]. Besides these benefits, iron can also be hazardous to organisms because $\mathrm{Fe}^{2+}$ triggers Fenton/HaberWeiss reaction that produces harmful reactive oxygen species (ROS) such as superoxide $\left(\mathrm{O}_{2}\right)$, hydrogen peroxide $\left(\mathrm{H}_{2} \mathrm{O}_{2}\right)$ and the highly destructive hydroxyl radical $(\mathrm{OH})$ [2]. There are certain models that 
showed that iron accumulation increased cell oxidants that triggered the early activation of redoxsensitivity with a stronger co-relation [3]. These ROS causes damage to [Fe-S] clusters, membrane lipid peroxidation, DNA damage, protein carbonylation, and Cys/Met-residue oxidation [4]. [5]Studied that the siderophore released by bacteria defends against oxidative stress and the protection was independent of iron availability. There are also studies where addition of iron stimulated the growth of M.aeruginosa and Chl-a production where $100 \mu \mathrm{M}$ caused the dramatic oxidative stress in algal cells whereas in $10 \mu \mathrm{M}$ it covered the cells. Adding to this microbial siderophores has also alleviated the metal induced oxidative stress in plants.

The strain Chlorella variabilis ATCC PTA 12198 is as an important feedstock for biofuel production owing to its higher biomass productivity, carbohydrate, lipid content, and also its capability to grow in several types of wastewater [7].It is important to choose microbial species like (bacteria, microalgae,etc.) with the aim of co-culture for growth promotion and lipid production and very recently, [8] developed sustainable process based on a mixed co-dominant culture of Saccharomyces cerevisiae and Chlorella vulgaris, in order to encourage the interaction of two different cultures, the medium design, culture conditions and inoculum ratio are very important which has been also discussed. In the present study $C$. variabilis(ATCCPTA 12198) was co-cultivated with Acinetobacter soli(MTCC - 5918) [9]to check its growth and lipid enhancement. Specific quorum sensing signals are detected in Acinetobacter species that can interact with their host [10] microalgae and can be further evaluated to find out optimum growth period for higher biomass generation. Axenic cultures are important for high value products like nutraceuticals and pharmaceuticals, but for biofuel production axenic cultures are not essential, hence for improving the growth and lipid productivity co-cultivation strategies can be employed. Similar reports are present where Mesorhizobium and Azospirillum bacteria (vice versa) through nitrogen fixation and Chlorella vulgaris ATCC 13482 and Pseudomonas sp. interact each other to produce polysaccharises and exchange nutrients [11]. From our previous study [12] we found that $C$. variabilis was able to grow in the presence of Idiomarina loihiensis RS14 when inoculated in optimum conditions. But, with the increase of bacterial inoculum, microalgae growth started declining. Due to the extreme consumption of iron siderophore, it forms and destructs the ROS, a blanket term to collect relatively reduced $\mathrm{O}_{2}$ containing molecules that possess peroxides $\left(\mathrm{H}_{2} \mathrm{O}_{2}\right)$, superoxide $\left(\mathrm{O}_{2}\right)$, and also free radicals $(\mathrm{HO})$ [13]. There are many reports showing that increase in the metals can induce ROS and siderophores may increase the susceptibility of microorganisms to oxidative damage [14]. Iron influences in generating harmful oxygen radicals, hence, under oxidative stress conditions, iron management stimulates exposure to this compound.By favoring iron release, hydrolysis of the catechole iron complex assures its iron needs and also provides the cell with a molecule, exposed to hydroxyl groups. This molecule can scavenge radicals that reduces various oxidative stresses. Therefore, the present study addresses the question of whether the co-cultivated microalgae is under oxidative stress at higher concentration of siderophore production. Addition to this, experiments were conducted to check, whether lipid and carbohydrate contents are influenced by nonmetal oxygen radical generator.

\section{Results And Discussions}




\section{Effect of standard siderophore on ROS activity}

Microalgae has the ability to activate several defence systems for scavenging the ROS that are generated in various cellular sections. During unfavourable conditions, the rate of ROS generation exceeds their scavenging rate, and causes oxidative damage to the cells [30]. This strategy was observed with respect to siderophore concentration. As siderophore has high affinity towards chelating iron, and iron is an important co-factor in ROS generation, hence different concentration of siderophore was taken to investigate the accumulation of $3 \mathrm{ROS}\left(\mathrm{H}_{2} \mathrm{O}_{2}, \mathrm{O}_{2}\right.$, and $\left.\mathrm{OH}\right)$. We observed that with the increase in the concentration $(50 \mu \mathrm{g})$ of siderophore, oxidative stress started increasing (Fig. 1a, 1b, 1c). At different concentration of siderophore, variation in accumulation of different ROS content was observed. $\mathrm{OH}$ content was increased to $(68.11 \pm 11.24 \mu \mathrm{M} / \mathrm{g} \mathrm{FW}$ ) (Fig. 1a) at $50 \mu \mathrm{g}$ siderophore concentration but The $\mathrm{H}_{2} \mathrm{O}_{2}$ content (Fig. 1c) decreased significantly $(P<0.05)$ nearly four folds $(20.15 \pm 0.28 \mu \mathrm{M} / \mathrm{g} \mathrm{FW})$ than the control (74.15 $\pm 3.22 \mu \mathrm{M} / \mathrm{g} \mathrm{FW})$. According to Fan et al. 2014 in Chlorella pyrenoidosa, $\mathrm{OH}$ and MDA content increased under iron deficiency. It can be further noted that pyochelin type siderophore could catalyse invitro through Haber-Weis reaction generating reactive oxygen species. Taking into account that certain siderophore in higher concentration also induced the microalgal inhibition which is contradictory to the reports by [31] that siderophore played as a protector against oxidative stress. As shown in Fig. 1b, $\mathrm{SO}_{2}$ content significantly increased $(P<0.05)$ with the increased concentration of added siderophore from $10 \mu \mathrm{g}(13.31 \pm 0.25)<30 \mu \mathrm{g}(91.58 \pm 2.16)<50 \mu \mathrm{g}(98.15 \pm 2.85)$. Unlike to this, $\mathrm{H}_{2} \mathrm{O}_{2}$ content decreased significantly $(P<0.05)$ with the increased concentration of siderophore i.e. (21.56).

\section{Effect of extracted and purified siderophore on ROS activity}

After observing results from standard siderophore, extracted and purified crude siderophore was added to the microalgal media with the previous described concentration to check the accumulation of ROS content. An increase in concentration of $\mathrm{OH}$ and $\mathrm{H}_{2} \mathrm{O}_{2}$ content was observed as compared to $\mathrm{SO}_{2}$ content. The fluctuating levels of ROS in all iron-starved cultures with the added siderophore propose a variance in the degree of a cellular defense response. Apart from $10 \mu \mathrm{g}$, both in $30 \mu \mathrm{g}$ and $50 \mu \mathrm{g}$, the $\mathrm{OH}$ content showed significantly $(P<0.05)$ similar trend i.e. $(65.25 \pm 0.11)$ and $(66.11 \pm 0.15)$ respectively. Moreover, we also observed similar results in $\mathrm{SO}_{2}$ content, i.e. $30 \mu \mathrm{g}$ and $50 \mu \mathrm{g}$ siderophore concentration showed $(95.58 \pm 0.21)$ and $(91.15 \pm 0.19)$ of $\mathrm{SO}_{2}$ with not much significant difference. In both Fig. $2 \mathrm{a}$ and $2 \mathrm{~b}$, we can observe that at $10 \mu \mathrm{g}$ both $\mathrm{SO}_{2}$ and $\mathrm{OH}$ content were lower even after 15 days. This might be because growth inhibition triggered due to the generation of high ROS toxicity during iron deficiency. Benderliev also observed similar results where $\mathrm{H}_{2} \mathrm{O}_{2}$ contentincreasedin Scenedesmus incrassatulus under ironlimited conditions [32]. Morrissey also observed significant increase in $\mathrm{H}_{2} \mathrm{O}_{2}$ content under iron starvation [33].

\section{Effect of co-cultivation of microalgae on ROS activity}

To observe the involvement of siderophore producing bacteria $A$. solitowards the accumulation of ROS content in the co-cultivated green algae $C$. variabilis, growth media was prepared in both iron sufficient 
and deficient conditions as described in the previous section. According to earlier reports increase of metal content increases oxidative stress [34].This promoted to observe the oxidative stress response in microalgae during iron stress conditions by increasing the bacterial supplement that produces siderophores. Hence, to address this, co-cultured microalgae was compared with axenic microalgae leading to the effect of producing three ROS $\left(\mathrm{H}_{2} \mathrm{O}_{2}, \mathrm{O}_{2}\right.$, and $\left.\mathrm{OH}\right)$. We observed significant increase of $\mathrm{OH}$ content $(71.11 \pm 8.12 \mu \mathrm{M} / \mathrm{g} \mathrm{FW})$ in co-cultured microalgae with the increase in time compared to axenic microalgae i.e. $(40.21 \pm 3.12 \mu \mathrm{M} / \mathrm{g} \mathrm{FW})$. Contrary to above experiments of direct involvement of siderophores to the microalgae, the co-cultured cells showed increase in all the ROS contents. The $\mathrm{SO}_{2}$ content increased significantly $(P<0.05)$ to $56 \%$ from $(37.31 \pm 3.18 \mu \mathrm{M} / \mathrm{g} \mathrm{FW})$ in axenic cells to $(101.15 \pm$ $13.12 \mu \mathrm{M} / \mathrm{g} \mathrm{FW}$ ) in co-cultured cells. Similarly the $\mathrm{H}_{2} \mathrm{O}_{2}$ content also increased simultaneously to $49 \%$ from $(64.14 \pm 2.11 \mu \mathrm{M} / \mathrm{g} \mathrm{FW})$ in axenic cells to $(131.56 \pm 23.18 \mu \mathrm{M} / \mathrm{g} \mathrm{FW})$ in co-cultured cells. Yilancioglu also observed similar results in $D$. salina where both ROS production as well as lipid peroxidation was increased under co-cultured conditions [35]. We can observe in all the following Fig. 3a, 3b, and $3 c$ that in co-cultured microalgae under iron deficient conditions the level of ROS increased significantly $(P<0.05)$ compared to axenic cultures. The release of chelators in presence of iron seems to be an adaptive strategy, both because free iron is practically insoluble at neutral and alkali $\mathrm{pH}$ and because of its potential toxicity. Another possible reason behind this might be the $\mathrm{Fe}^{3+}$ induced release of chelators enhancing the capacity of cells to scavenge and later to take up iron [36].

\section{Effect of co-cultivation on microalgalbiomass productivity}

Convinced by the results in $(5: 1)$ volumetric ratio, $A$. soli with $C$. variabilis were co-cultivated in iron sufficient and deficient conditions at higher scale $(500 \mathrm{~mL})$ to check its potential role in the growth enhancement of micro algae. Under iron deficient conditions the DCW of axenic culture was $(202.2 \pm$ $\left.2.02 \mathrm{mg} \mathrm{mL}^{-1}\right)$ and co-cultured was $\left(240.6 \pm 1.04 \mathrm{mg} \mathrm{mL}^{-1}\right)$ which shows there was not any significant increase in the biomass of co-cultured microalgae. In iron sufficient conditions DCW of axenic culture was $\left(320.8 \pm 1.36 \mathrm{mg} \mathrm{mL}^{-1}\right)$ and co-cultured was $\left(138.1 \pm 3.24 \mathrm{mg} \mathrm{mL}^{-1}\right)$ that shows a reduction of (61.7\%) of DCW of co-cultured compared to axenic microalgae (Fig. 4). It can be interpreted due to the iron overload in the media the presence of both iron source and secretion of siderophores in the growth media becomes toxic [37].

\section{Effect of co-cultivation of microalgae on ash and pigment contents}

Ash and pigments contents were measured for comparative studies between effects on co-cultivation and axenic culture of microalgae. Examination of ash content obtained indicated significant differences between axenic and co-cultivated microalgae. In iron sufficient medium ash content of co-cultivated microalgae showed $32 \%$ and in iron deficient medium showed $14.23 \%$ which shows $44 \%$ decrease of ash content. Concomitantly, there was only $3.87 \%$ of increase in ash content in co-cultivated microalgae compared to axenic in iron deficient medium. The increase of ash content in co-cultivated microalgae is due to the association of bacteria with microalgae. Similar results were observed in [22] where high ash 
content of algae was observed when algae was contaminated with diatoms or sandy particles. During initial test at different inoculum ratio chlorophyll- a content was similar in algal cells over a period of 15 days at (5:1) ratio in both axenic and co-cultured (data not shown). But during the scaled up test, when chlorophyll content was compared to algae \& bacteria in iron deficient medium with only algae in iron sufficient conditions, both showed similar results (Table 2). It was observed that highest chlorophyll-a $\left(13.06 \mu \mathrm{g} \mathrm{mL}^{-1}\right)$, chlorophyll-b $\left(7.24 \mu \mathrm{g} \mathrm{mL}^{-1}\right)$ were found in co-cultivated culture under iron starvation, which was significantly higher $(\mathrm{P}<0.05)$ than the axenic culture under iron deficient conditions. It was again similar with the axenic and co-cultured under iron sufficient conditions.Effect of siderophore on chlorophyll was previously observed by [38] and found higher pigment concentration than the control ones

Table 1

Estimation of Ash content of axenic and co-culture $C$. variabilis in iron sufficient and deficient conditions. YA and YAB are algae and algae with bacteria in the presence of iron. NA and NAB are algae and algae with bacteria in the absence of iron. The results are presented as the average \pm standard deviation (SD). Means with a common letter are not significantly different $(p>0.05)$

\begin{tabular}{|ll|}
\hline Treatments & Ash Content (\%) \\
\hline YA & $2.97^{\mathrm{ab}}$ \\
\hline YAB & $32^{\mathrm{b}}$ \\
\hline NA & $0.55^{\mathrm{a}}$ \\
\hline NAB & $14.23^{\mathrm{a}}$ \\
\hline
\end{tabular}


Table 2

Estimation of pigment composition of axenic and co-culture $C$. variabilis in iron sufficient and deficient conditions. YA and YAB are algae and algae with bacteria in the presence of iron. NA and NAB are algae and algae with bacteria in the absence of iron. The results are presented as the average \pm standard deviation (SD). Means with a common letter are not significantly different $(p>0.05)$

\begin{tabular}{|c|c|c|c|c|c|c|}
\hline Treatments & $\begin{array}{l}\text { Chl a } \\
(\mu \mathrm{g} / \mathrm{mL})\end{array}$ & $\begin{array}{l}\text { Chl b } \\
(\mu \mathrm{g} / \mathrm{mL})\end{array}$ & $\begin{array}{l}\text { Chl }(a+b) \\
(\mu g / m L)\end{array}$ & $\begin{array}{l}\text { Chl (a /b) } \\
(\mu \mathrm{g} / \mathrm{mL})\end{array}$ & $\begin{array}{l}\text { Caro } \\
(\mu \mathrm{g} / \mathrm{mL})\end{array}$ & $\begin{array}{l}\text { Caro/Chlo }(a+b) \\
(\mu \mathrm{g} / \mathrm{mL})\end{array}$ \\
\hline YA & $\begin{array}{l}12.01 \pm \\
0.32^{a}\end{array}$ & $\begin{array}{l}7.02 \pm \\
0.29^{a}\end{array}$ & $\begin{array}{l}19.03 \pm \\
0.61^{\mathrm{a}}\end{array}$ & $1.71 \pm 1.10^{a}$ & $\begin{array}{l}14.01 \pm \\
1.23^{\mathrm{a}}\end{array}$ & $0.73 \pm 2.01^{\mathrm{a}}$ \\
\hline YAB & $\begin{array}{l}5.23 \pm \\
0.24^{\mathrm{a}}\end{array}$ & $\begin{array}{l}2.56 \pm \\
0.41^{b}\end{array}$ & $\begin{array}{l}7.79 \pm \\
0.65^{\mathrm{ab}}\end{array}$ & $2.04 \pm 0.58^{a}$ & $\begin{array}{l}8.02 \pm \\
2.15^{a}\end{array}$ & $1.02 \pm 3.30^{a}$ \\
\hline NA & $\begin{array}{l}7.12 \pm \\
0.36^{a}\end{array}$ & $\begin{array}{l}3.23 \pm \\
0.36^{\mathrm{b}}\end{array}$ & $\begin{array}{l}10.35 \pm \\
0.72^{a b}\end{array}$ & $2.20 \pm 1.00^{a}$ & $\begin{array}{l}10.01 \pm \\
0.06^{\mathrm{a}}\end{array}$ & $0.96 \pm 0.08^{a}$ \\
\hline NAB & $\begin{array}{l}13.06 \pm \\
0.25^{\mathrm{a}}\end{array}$ & $\begin{array}{l}7.24 \pm \\
0.54^{\mathrm{a}}\end{array}$ & $\begin{array}{l}20.30 \pm \\
0.79^{a}\end{array}$ & $1.80 \pm 0.46^{a}$ & $\begin{array}{l}9.02 \pm \\
0.14^{\mathrm{a}}\end{array}$ & $0.44 \pm 0.17^{\mathrm{a}}$ \\
\hline
\end{tabular}

\section{Effect on quantum yield of photosystem II}

During nutrient limitation in microalgae, ROS are formed due to the impairing of electron transport chain wherein the electron flows from the photosystems to it. It is illustrated by the decrease in $F_{\mathrm{v}} / F_{\mathrm{m}}$ due to nutrient limitation [39] indicating PS-II being negatively influenced [40]. In the present study, $F_{\mathrm{v}} / F_{\mathrm{m}}$ increased significantly $(P<0.05)$ in co-cultured microalgae $(0.596 \pm 0.019)$ compared to axenic microalgae $(0.321 \pm 0.021)$ in iron deficient conditions (Table 3$)$. In iron sufficient conditions cultures exhibited $F_{\mathrm{v}} / F_{\mathrm{m}}$ of $(0.498 \pm 0.014)$, which was nearly similar to that of the co-cultured microalgae. These results are accordance with that of the pigments contents confirming that these co-cultured organisms during iron starvation significantly affects the photosynthetic apparatus of $C$. variabilis. 
Table 3

Estimation quantum yield of photosystem II of axenic and coculture $C$. variabilis in iron sufficient and deficient conditions. $Y A$ and $Y A B$ are algae and algae with bacteria in the presence of iron. NA and $\mathrm{NAB}$ are algae and algae with bacteria in the absence of iron. The results are presented as the average \pm standard deviation (SD). Means with a common letter are significantly different $(p>0.05)$

\begin{tabular}{|ll|}
\hline Treatments & Fv/Fm \\
\hline YA & $0.392 \pm 0.014^{\mathrm{a}}$ \\
\hline YAB & $0.498 \pm 0.022^{\mathrm{b}}$ \\
\hline NA & $0.321 \pm 0.021^{\mathrm{a}}$ \\
\hline NAB & $0.596 \pm 0.019^{\mathrm{a}}$ \\
\hline
\end{tabular}

Effect of co-cultivation on microalgal total lipid, carbohydrate and proteins

Carbon fixation through photosynthesis is used for the production of major macromolecules like proteins, carbohydrates and lipids. In the current study, the highest protein content of (44.58 $\pm 0.87 \%)$ was observed in the control (iron sufficient condition) in axenic microalgae (Fig. 5) but, reduced significantly $(P<0.05)$ to $(29.46 \pm 0.92 \%)$ in co-cultured microalgae in iron sufficient conditions. In the present study, lipid content of $C$. variabilis was significantly higher $(\mathrm{P}<0.05)$ in co-cultured microalgae under iron deficient treatments when compared to control culture (Fig. 5). It was highest $(45.92 \pm 0.74 \%)$ in cocultured microalgae which was about $21 \%$ higher than the axenic microalgae $(25.31 \pm 1.20 \%)$. Under iron deficiency, a significant trigger in the lipid accumulation by various microalgae like Chlorella vulgaris[41], Dunaliella salina[35], Chlorella sorokiniana[42], Nannochloropsis oceanica[43] are reported previously. In our results, although there were no significant changes in the micro-algal growth, but, there was significant $(P<0.05)$ increase in lipid, carbohydrate and the protein content of the cells (Fig. 5) supporting the above perception. Microalgal carbohydrates are the potential resource for production of bioethanol, due to its various benefits like easy hydrolysis, easy conversion to fermentable sugars, and no harsh pretreatment [44]. When compared to lipid accumulation, similar results were obtained in carbohydrate content, where $C$. variabilis also increased in the co-cultured microalgae under iron deficient conditions (Fig. 5). It was maximum (41.80 $\pm 5.03 \%)$ in co-cultured microalgae, which was about $40 \%$ higher than that of the control culture $(30.21 \pm 2.12 \%)$. From the biochemical composition of $C$. variabilis it could be inferred that co-cultured microalgae under iron starvation can be preferred for producing higher biomass, lipid and carbohydrate contents. 


\section{Effect of co-cultivation on lipid fragments in microalgae}

As microalgal lipids are fractionalised into three major components NLs, GLs, and PLs, hence to observe the effects of co-cultured on the lipid composition of $C$. variabilis under iron deficient medium, total lipids were further fractionated by a column chromatography. Figure 6 shows that PLs of the cells decreased significantly $(P<0.05)$ in co-cultured microalgae compared to axenic microalgae, i.e., $(21.62 \pm 0.80 \%)$ in axenic microalgae to $(9.90 \pm 0.90 \%)$ in co-cultured microalgae. The accumulation of NLs was almost similar in all the treated cells $(70-80 \pm 0.40 \%)$ except in axenic microalgae in iron deficient condition i.e. $(60.12 \pm 0.51 \%)$. The GLs decreased significantly $(P<0.05)$ from $(19.89 \pm 2.69 \%)$ in control to $(14.39 \pm$ $0.62 \%)$ in iron deficient conditions. Under iron deficiency the co-cultured showed increase in neutral lipid i.e. $(77.05 \pm 0.21 \%)$ compared to axenic microalgae $(60.12 \pm 0.11 \%)$. Our results are accordance to the previous observations that suggests that in exponential phase the availability of optimal iron increases both biomass and lipid production [45].

\section{Conclusion}

In the present study, we investigated microalgal growth and the biofuel potential of green microalga C.variabilis (ATCC-PTA 12198) with A.soli (MTCC-5918) through co-cultivation strategy. Different efforts were made to link the lipid and carbohydrate content with the oxidative stress by the addition of siderophore under iron deficiency. The results of the present study showed the interaction of siderophoreinduced oxidative stress with the signalling in the growth and development of the C.variabilis. Lipid and carbohydrate content were highest in co-cultured microalgae. In the cell, $\mathrm{O}_{2}$ is either directly catalysed to $\mathrm{H}_{2} \mathrm{O}_{2}$, by the action of SOD which produces $\mathrm{OH}$ through the Fenton reaction, or $\mathrm{OH}$ via Haber-Weiss cycle. $\mathrm{OH}$ levels were similar in all three iron-starved co-cultured cultures, but there was a significant difference in the accumulation of $\mathrm{H}_{2} \mathrm{O}_{2}$ and $\mathrm{O}_{2}$. Though, there was not much increase in the microalgal growth in co-cultured microalgae but, the lipid and carbohydrate content increased. Future research could be focused on how the oxidative stress is triggered by iron through siderophore affecting the biochemical changes on microalgae. Hence, this study provides new approach to improve the biofuel potential of the promising strain of the $C$.variabilis through co-cultivation strategy presenting a comprehensive picture of oxidative stress of the cells instead of cultivating the isolated strains for the purpose of biofuel as it requires many challenges to be faced while shifting from high value low volume products during scale up for commercial production.

\section{Methods}

\section{Experimental conditions}

Tests conducted in this section were aimed to observe the production of ROS in microalgae due to the increase in the production of siderophore. Initial experiments were conducted in microalgae Chlorella variabilis under iron limiting conditions by inoculating standard siderophore as preliminary test and then 
siderophore producing bacteria Acinetobacter soli to scale it up to $1 \mathrm{~L}$. The concentration of siderophore was increased in all the experiments to check the level of ROS production.

\section{Micro-algal growth conditions}

The axenic micro-algal culture was grown in Zarrouk's medium [15] in both iron sufficient and iron deficient conditions. In iron deficient it was grown with the exception that $\mathrm{FeSO}_{4}$ and EDTA was omitted following the cultivation recommendations for this algal strain, and the medium was referred to as $\mathrm{Fe}$ deficient media. In a Percival chamber microalgae was grown in static cultures at $18^{\circ} \mathrm{C}$ under a light/dark cycle of $12 / 12 \mathrm{~h}$. Light intensity was $150 \mu$ moles photons $\mathrm{m}^{-2} \mathrm{~s}^{-1}$. A mixture of penicillin and streptomycin at a final concentration of $(0.5 \mathrm{mg} / \mathrm{mL}$ and $1 \mathrm{mg} / \mathrm{mL})$ was used to maintain axenic cultures. Cultures were maintained axenic respectively. The cultures treated with antibiotics were used to inoculate antibiotic free cultures before preliminary experimental procedure. Absence of bacteria in axenic micro-algal culture was monitored periodically both by spread-plate technique using Nutrient agar [16]and under the microscope. The initial microalgal concentration was the similar for all growth conditions by (4 $\times 10^{9}$ cells $/ \mathrm{mL}$ ) or $0.25 \mathrm{OD}$ (optical density) reading at $750 \mathrm{~nm}$. Micro-algal cell count was monitored initially using a hemocytometer.

\section{Bacterial growth conditions}

The bacterial strain of Acinetobacter soli was grown in liquid medium aerobically in chemically defined low iron media (CDLIM) constituted of $2 \mathrm{~g} \mathrm{~K}_{2} \mathrm{SO}_{4}, 3 \mathrm{~g} \mathrm{~K}_{2} \mathrm{HPO}_{4}, 1 \mathrm{~g} \mathrm{NaCl}, 5 \mathrm{~g} \mathrm{NH}_{4} \mathrm{Cl}, 2 \mathrm{mg}$ thiamine, $100 \mathrm{mg} \mathrm{CaCl} 2,0.005 \mathrm{mg} \mathrm{CuSO}_{4}, 0$ mg MgSO ${ }_{4} .7 \mathrm{H}_{2} \mathrm{O}, 2 \mathrm{mg} \mathrm{ZnSO}_{4} .7 \mathrm{H}_{2} \mathrm{O}, 0.0035 \mathrm{mg} \mathrm{MnSO}_{4}, 2.5 \%$ glycerol stock at $28^{\circ} \mathrm{C}$ and $120 \mathrm{rpm}$ for $120 \mathrm{~h}$ that was specially designed for production of siderophores [17]. Cultures were incubated at $30^{\circ} \mathrm{C}$ shaking at $120 \mathrm{rpm}$.

\section{Extraction and purification of siderophore}

Bacterial isolate was cultured in Nutrient broth (Himedia) medium at $30^{\circ} \mathrm{C}, 180 \mathrm{rpm}$ for $24 \mathrm{~h}$. The cultures were harvested by centrifugation at $10,000 * \mathrm{~g}$ for $15 \mathrm{~min}$ at $4^{\circ} \mathrm{C}$. The cell free supernatant was acidified to $\mathrm{pH} 2.5$ and added with Amberlite XAD-2 resin, (ca. $100 \mathrm{~g} \mathrm{~L}^{-1}$, Himedia) to absorb the siderophore [18]. The resin was poured into column and washed several bed volume of deionised water to remove salt followed by the suspension was shaken for $12 \mathrm{~h}$. Methanol $(100 \%)$ was then used for final elution further which concentrated by rotary evaporation (Buchi-R215) to yield the crude extract [19]. Crude siderophore extracts was purified on a size exclusion column (Sephadex G-10, GE Healthcare). The recovered fractions containing siderophore were identified by CAS assay [20] pooled and then subjected to reversedphase high-performance liquid chromatography (RP-HPLC) for further purification. Purified siderophore was lyophilized and stored at $-20^{\circ} \mathrm{C}$.

\section{Estimation of standard siderophore on ROS activity}

C. variabilis grown in $\mathrm{ZM}$ was transferred in flask washed with $\mathrm{HCl}$ that contained fresh media supplemented with standard siderophore. Both positive and negative control was prepared according to 
our previous work [12]. Purified siderophore ranging $10 \mu \mathrm{g}, 30 \mu \mathrm{g}, 50 \mu \mathrm{g}$, was added in iron deficient medium. All the experiments were performed in triplicates.

\section{Estimation of extracted and purified siderophore on ROS activity}

The crude siderophore, after purification as described in the (sec 2.1.3) was added in to the media containing microalgae. The concentration of siderophore kept same as described in the (sec 2.1.4). Estimation of biomass productivity

Biomass productivity was observed according to following equation.

$P=(X 2-X 1) /(t 2-t 1)$,

Where, $\mathrm{X} 2$ and $\mathrm{X} 1$ are the dry cell weight concentration $(\mathrm{mg} / \mathrm{L})$ at time $\mathrm{t} 2$ and $\mathrm{t} 1$, respectively $\mathrm{BP}$ was calculated in terms of (mg/L/day). The optical density at $750 \mathrm{~nm}$ was estimated for the growth of microalgae [12].

\section{Estimation of quantum yield of photosystem II}

The maximum quantum yield ( Fv/Fm) of photosystem II (PS II) was measured using a fluorometry i.e. Pulse Amplitude-Modulated (PAM) by (AquaPen-C AP-C100, Photon System Instruments). Cultures were diluted appropriately to an absorbance (OD at $750 \mathrm{~nm}$ ). Fluorescence of the samples was measured after the cells were adapted to 30 min darkness. This dark-adapted fluorescence with minimal level $(F O)$ and the fluorescence with maximal level measured after high intensity of short light pulse $(F \mathrm{~m})$ were used to calculate $\mathrm{Fv} / \mathrm{Fm}$ according to the following equation:

$F V / F m=(F m-F 0) / F m[21]$.

\section{Estimation of ash content and pigments of microalgae}

The ash content in microalgae is measured gravimetrically by a process called dry ashing or dry oxidation i.e burning samples in a muffle furnace at a high temperature for a specified duration. Ashing temperature was adjusted to $600{ }^{\circ} \mathrm{C}$ for at least $30 \mathrm{~min}$ [22]. Pigment content was estimated in the pellet after centrifugation of $2.0 \mathrm{~mL}$ of culture at $10,000 \mathrm{rpm}$ for $15 \mathrm{~min}+2.0 \mathrm{~mL}$ of $100 \%$ methanol, mixed well and incubated at $450 \mathrm{C}$ for $24 \mathrm{~h}$ in the dark. The total pigment content was calculated according to following equations:

Chlorophyll a; Chl-a $(\mathrm{l} \mu \mathrm{g} / \mathrm{mL})=16.72(\mathrm{~A} 665.2)-9.16(\mathrm{~A} 652.4)$

Chlorophyll b; Chl-b $(\mathrm{l} \mu \mathrm{g} / \mathrm{mL})=34.09(\mathrm{A652.4})-15.28(\mathrm{A665.2})$

Carotenoids $(\mathrm{l} \mu \mathrm{g} / \mathrm{mL})=[1000(\mathrm{~A} 470)-1.63(\mathrm{Chl}-\mathrm{a})-104.9(\mathrm{Chl}-\mathrm{b})] / 221[12]$

Estimation of lipid and crude protein contents 
Lipids were extracted by the method of (Bligh and Dyer 1959) (a mixture of chloroform and methanol) and quantified gravimetrically with separation through column chromatography [23]. Biomass was vortexed thoroughly, ultrasonicated at room temperature in chloroform:methanol $(1: 2, \mathrm{v} / \mathrm{v})$, centrifuged and measured gravimetrically. Lipids are mainly phospholipids (PL), glycolipids (GL) and neutral lipids $(\mathrm{NL})$. All the above fractions are fractionated by sequential elution by chloroform:acetic acid $(9: 1, \mathrm{v} / \mathrm{v})$ for neutral lipid, acetone:methanol (9:1, v/v) for glycolipids and 100\% methanol for phospholipids after drying at $60^{\circ} \mathrm{C}$ [24]. Crude protein was estimated according to [25].

\section{Estimation of carbohydrate}

Carbohydrate was determined by the addition of $100 \mathrm{mg}$ dried biomass with $10 \mathrm{~mL}$ of $2 \% \mathrm{H}_{2} \mathrm{SO}_{4}$ and then hydrolysed at $121^{\circ} \mathrm{C}$ for $20 \mathrm{~min}$. Further $\mathrm{CaCO}_{3}$ was used to neutralize and diluted to $100 \mathrm{~mL}$ distilled water. The total sugar content in supernatant was estimated after centrifugation at 10,000 rpm for $5 \mathrm{~min}$ [26].

\section{Estimation of ROS activity}

The $\mathrm{H}_{2} \mathrm{O}_{2}$ content of microalgal cells was measured by harvesting the culture by centrifugation and the cell pellet was homogenized in $0.1 \% \mathrm{w} / \mathrm{V}$ TCA solution. The obtained homogenate was centrifuged at $15,000 \times g$ for $20 \mathrm{~min} .0 .5 \mathrm{~mL}$ supernatant of obtained aliquot was mixed with $0.5 \mathrm{~mL}$ of phosphate buffer ( $10 \mathrm{mM}$ and $\mathrm{pH} 7.0$ ) and $1 \mathrm{~mL}$ of $1 \mathrm{M}$ potassium iodide and its absorbance was read at $390 \mathrm{~nm}$ [27]. The $\mathrm{H}_{2} \mathrm{O}_{2}$ concentration ( $\mu \mathrm{mol} \mathrm{H} \mathrm{H}_{2} \mathrm{O}_{2} / \mathrm{g} \mathrm{FW}$ ) was determined with the help of a calibration curve. $\mathrm{O}_{2}$ content of microalgal cells was measured by harvesting it by centrifugation and the homogenized with $5 \mathrm{~mL}$ of potassium phosphate buffer $(65 \mathrm{mM}, \mathrm{pH} 7.8)$. This homogenate was centrifuged at $14,000 \times \mathrm{g}$ for 10 min and. $1 \mathrm{~mL}$ supernatant of obtained aliquot was mixed with $0.9 \mathrm{~mL}$ of potassium phosphate buffer $(65 \mathrm{mM}, \mathrm{pH} 7.8)$ and $0.1 \mathrm{~mL}$ of hydroxyl ammonium chloride $(10 \mathrm{mM})$. The solution was incubated at $25^{\circ} \mathrm{C}$ for $20 \mathrm{~min}$, afterwards, $1 \mathrm{~mL}$ of sulphanilic acid $(17 \mathrm{mM})$, and $1 \mathrm{~mL}$ of a-naphthylamine $(7 \mathrm{mM})$ were added to it. It was again incubated for $20 \mathrm{~min}$, and the absorbance of was read at $530 \mathrm{~nm}$ [28]. OH content, microalgal cells was measured by harvesting it by centrifugation and homogenized with $2 \mathrm{~mL}$ of potassium phosphate buffer $(50 \mathrm{mM}, \mathrm{pH} 7.0)$. This homogenate was again centrifuged at $14,000 \times \mathrm{g}$ for 10 min. Consequently, $0.5 \mathrm{~mL}$ of supernatant was mixed with $0.5 \mathrm{~mL}$ of potassium phosphate buffer (50 mM, pH 7.0). At $35^{\circ} \mathrm{C}$ in dark, the reaction was established for $1 \mathrm{~h} .1 \mathrm{~mL}$ of $1 \%$ TBA and $1 \mathrm{~mL}$ of acetic acid was added to $0.05 \mathrm{M}$ sodium hydroxide, and the mixture was boiled for 30 min that was again cooled on ice immediately. The absorbance of this solution was read at $532 \mathrm{~nm}$ [29].

\section{Statistical analysis}

All the experiments were carried out in triplicates. Statistical data presented here are generated from three independent experiments. All statistical significance comparisons between indicated groups were performed using a one-way ANOVA with Fisher's post-test.

Data presented are mean values and their standard deviation.

\section{Declaration of competing interest}


Ethics approval and consent to participate

No conflicts, informed consent, or human or animal rights are applicable to this study"

Consent for publication

Not applicable.

Availability of data and materials

All data generated and analyzed in this study are included in this published article.

\section{Abbreviations}

CAS- Chrome Azurol Sulphonate

DCW - Dry cell weight

DW- Dry weight

$\mathrm{Fe}^{2+}$ - Ferrous oxide

[Fe-S]-Iron-Sulphur cluster

$F_{\mathrm{v}} / \mathrm{F}_{\mathrm{m}}$ - Maximum quantum yield of photosystem II

FW - Fresh weight

GL- Glyco Lipid

$\mathrm{H}_{2} \mathrm{O}_{2}$ - Hydrogen Peroxide

MDA-Malondialdehyde

NL- Neutral Lipid

$\mathrm{O}_{2}$ - Superoxide radicals

$\mathrm{OH}^{*}$ - Hydroxyl radicals

PL- Phospholipid

PS II - Photosystem II

ROS- Reactive Oxygen Species

$\mathrm{SO}_{2}$ - Sulphur dioxide 
SOD - superoxide dismutase

TBA - Thiobarbituric acid

ZM-Zarrouk's Media

\section{Declarations}

Ethics approval and consent to participate

No conflicts, informed consent, or human or animal rights are applicable to this study"

Consent for publication

Not applicable.

Availability of data and materials

All data generated and analyzed in this study are included in this published article.

Competing interest

The authors declare that they have no known competing financial interests or personal relationships that could have appeared to influence the work reported in this paper.

Funding

RS acknowledges DST for her INSPIRE funding support. PB acknowledges CSIR-SRF for the funding support. VB acknowledges CSIR-SRF for the funding support. RS, PB and VB acknowledge AcSIR for their Ph.D. enrolment.

Author's contributions

Dr Sandhya Mishra Conceptualized the idea for co-cultivation strategy to enhance the growth, lipids and carbohydrates. Further designing for the experiments, which were actually performed, by Soundarya Rajapitamahuni and Pooja Bachani, Vamsi Bharadwaj S.V. has helped in the molecular identification of the strains used in the experiments. Dr Sandhya Mishra edited manuscript.

Acknowledgments

Registration Number PRIS CSIR-CSMCRI -138/2019 has been assigned to the manuscript. We are thankful to Dr. Kaumeel Chokshi for helping in determining ROS activity.

\section{References}


1. Cornelis $P$, Wei $Q$, Andrews SC, Vinckx T. Iron homeostasis and management of oxidative stress response in bacteria. Metallomics. 2011;3(6):540-9.

2. Cabiscol Català E, Sumalla T, J., \& Ros Salvador J. Oxidative stress in bacteria and protein damage by reactive oxygen species. International Microbiology, 2000, vol. 3, núm. 1, p. 3-8.

3. Sergent O, Griffon B, Morel I, Chevanne M, Dubos M, Cillard P, Cillard J. Effect of nitric oxide on ironmediated oxidative stress in primary rat hepatocyte culture. Hepatology. 1997;25(1):122-7.

4. Dixon SJ, Stockwell BR. The role of iron and reactive oxygen species in cell death. Nature chemical biology, 2014. 10(1).

5. Ferreira D, Seca AM, Diana CGA, Silva AM. Targeting human pathogenic bacteria by siderophores: a proteomics review. Journal of proteomics. 2016;145:153-66.

6. Wang C, Wang X, Wang P, Chen B, Hou J, Qian J, Yang Y,. Effects of iron on growth, antioxidant enzyme activity, bound extracellular polymeric substances and microcystin production of Microcystis aeruginosa FACHB-905. Ecotoxicology and environmental safety, 2016; 132, pp. 231-239.

7. Mishra SCP, Ghosh PK, Gandhi MR, Bhattacharya S, Maiti S, Upadhyay SC, Ghosh A, Prasad RBN, Kanjilal S, Mishra SK, Shrivastav AV. Engine worthy fatty acid methyl ester (biodiesel) from naturally occuring marine microalgal mats and marine microalgae cultured in open salt pans together with value addition of co-products. U.S. Patent Application, 2014; 14/119,065.

8. La A,. Process development for symbiotic culture of Saccharomyces cerevisiae and Chlorella vulgaris for in situ $\mathrm{CO}_{2}$ mitigation (Doctoral dissertation, Paris Saclay). 2019.

9. Bachani P, Bhattacharya S, Jain D, Patidar SK, Soundarya R, Tirkey SR, Ranawat B, Bharadwaj SV, Mishra S. Bioprospecting of halotolerant Bacterial Isolates for Potassium Recovery from K-Feldspar. Chemical Engineering Technology. 2016;39(9):1645-52.

10. Zhou J, Lyu Y, Richlen ML, Anderson DM, Cai Z. Quorum sensing is a language of chemical signals and plays an ecological role in algal-bacterial interactions. CRC Crit Rev Plant Sci. 2016;35(2):81105.

11. Molina D, de Carvalho JC, Júnior AIM, Faulds C, Bertrand E, Soccol CR. Biological contamination and its chemical control in microalgal mass cultures. Appl Microbiol Biotechnol. 2019;103(23-24):934558.

12. Rajapitamahuni S, Bachani P, Sardar RK, Mishra S. Co-cultivation of siderophore-producing bacteria Idiomarina loihiensis RS14 with Chlorella variabilis ATCC 12198, evaluation of micro-algal growth, lipid, and protein content under iron starvation. J Appl Phycol. 2019;31(1):29-39.

13. Shin B, Park C, Park W. Stress responses linked to antimicrobial resistance in Acinetobacter species. Applied Microbiology and Biotechnology, 2020;. 1-13.

14. Dao KHT, Hamer KE, Clark CL, Harshman LG. Pyoverdine production by Pseudomonas aeruginosa exposed to metals or an oxidative stress agent. Ecological applications. 1999;9(2):441-8.

15. Bhattacharya S, Maurya R, Mishra SK, Ghosh T, Patidar SK, Paliwal C, Mishra S. Solar driven mass cultivation and the extraction of lipids from Chlorella variabilis: A case study. Algal research. 
2016;14:137-42.

16. Brettar I, Christen R, Höfle MG. Idiomarina baltica sp. nov., a marine bacterium with a high optimum growth temperature isolated from surface water of the central Baltic Sea. Int J Syst Evol MicroBiol. 2003;53(2):407-13.

17. Bendale MS, Chaudhari BL, Chincholkar SB. Influence of environmental factors on siderophore production by Streptomyces fulvissimus ATCC 27431. Curr. Trends Biotechnol Pharm. 2010;3:36271.

18. Amin SA, Parker MS, Armbrust EV. Interactions between diatoms and bacteria. Microbiol Mol Biol Rev. 2012;76(3):667-84.

19. Vraspir JM, Butler A. Chemistry of marine ligands and siderophores. Annual review of marine science. 2009;1:43-63.

20. Schwyn B, Neilands JB. Universal chemical assay for the detection and determination of siderophores. Anal Biochem. 1987;160(1):47-56.

21. Chokshi K, Pancha I, Ghosh A, Mishra S Nitrogen starvation-induced cellular crosstalk of ROSscavenging antioxidants and phytohormone enhanced the biofuel potential of green microalga Acutodesmus dimorphus. Biotechnology for biofuels, 2017; 10(1), 60.

22. Liu K. Effects of sample size, dry ashing temperature and duration on determination of ash content in algae and other biomass. Algal Res. 2019;40:101486.

23. Bligh EG, Dyer WJ. A rapid method of total lipid extraction and purification. Canadian journal of biochemistry physiology. 1959;37(8):911-7.

24. Luque-Garcia JL, De Castro ML. Ultrasound-assisted soxhlet extraction: an expeditive approach for solid sample treatment: application to the extraction of total fat from oleaginous seeds. J Chromatogr A. 2004;1034(1-2):237-42.

25. Becker EW Microalgae: biotechnology and microbiology 1994; (Vol. 10). Cambridge University Press.

26. Dubois M, Gilles KA, Hamilton JK, Rebers PT, Smith F. Colorimetric method for determination of sugars and related substances. Analytical chemistry. 1956;28(3):350-6.

27. Velikova V, Yordanov I, Edreva A. Oxidative stress and some antioxidant systems in acid rain-treated bean plants: protective role of exogenous polyamines. Plant science. 2000;151(1):59-66.

28. Liu Y, Zhou Q, Xie X, Lin D, Dong L. Oxidative stress and DNA damage in the earthworm Eisenia fetida induced by toluene, ethylbenzene and xylene. Ecotoxicology. 2010;19(8):1551-9.

29. Halliwell B. Biochemistry of oxidative stress. 2007.

30. Gill SS, Tuteja N. Reactive oxygen species and antioxidant machinery in abiotic stress tolerance in crop plants. Plant physiology biochemistry. 2010;48(12):909-30.

31. Clarke SE, Stuart JA, N. I. CE, Sanders-Loehr JO. A. N. N. Induction of siderophore activity in Anabaenaspp. and its moderation of copper toxicity. Appl Environ Microbiol. 1987;53(5):917-22.

32. Benderliev KM, Ivanova NI, Pilarski PS. Singlet oxygen and other reactive oxygen species are involved in regulation of release of iron-binding chelators from Scenedesmus cells. Biologia plantarum. 
2003;47(4):523-6.

33. Morrissey J, Bowler C. Iron utilization in marine cyanobacteria and eukaryotic algae. Frontiers in microbiology. 2012;3:43.

34. Schutzendubel A, Polle A. Plant responses to abiotic stresses: heavy metal-induced oxidative stress and protection by mycorrhization. J Exp Bot. 2002;53(372):1351-65.

35. Yilancioglu K, Cokol M, Pastirmaci I, Erman B, Cetiner S. Oxidative stress is a mediator for increased lipid accumulation in a newly isolated Dunaliella salina strain. PLoS One. 2014;9(3):e91957.

36. Morel F, Doussiere J, Vignais PV. The superoxide generating oxidase of phagocytic cells: physiological, molecular and pathological aspects. Eur J Biochem. 1991;201(3):523-46.

37. Amin SA, Hmelo LR, Van Tol HM, Durham BP, Carlson LT, Heal KR, Morales RL, Berthiaume CT, Parker MS, Djunaedi B, Ingalls AE. Interaction and signalling between a cosmopolitan phytoplankton and associated bacteria. Nature. 2015;522(7554):98-101.

38. Dimkpa CO, Merten D, Svatoš A, Büchel G, Kothe E. Metal-induced oxidative stress impacting plant growth in contaminated soil is alleviated by microbial siderophores. Soil Biol Biochem. 2009;41(1):154-62.

39. Goiris K, Van Colen W, Wilches I, León-Tamariz F, De Cooman L, Muylaert K. Impact of nutrient stress on antioxidant production in three species of microalgae. Algal Res. 2015;7:51-7.

40. Kalaji HM, Jajoo A, Oukarroum A, Brestic M, Zivcak M, Samborska IA, Ladle RJ. Chlorophyll a fluorescence as a tool to monitor physiological status of plants under abiotic stress conditions. Acta physiologiae plantarum. 2016;38(4):102.

41. Liu T, Liu F, Wang C, Wang Z, Li Y. The boosted biomass and lipid accumulation in Chlorella vulgaris by supplementation of synthetic phytohormone analogs. Bioresour Technol. 2017;232:44-52.

42. Zhang $\mathrm{YM}$, Chen $\mathrm{H}, \mathrm{He} \mathrm{CL}$, Wang Q. Nitrogen starvation induced oxidative stress in an oil-producing green alga Chlorella sorokiniana C3. PloS one. 2013;8(7):e69225.

43. Jia J, Han D, Gerken HG, Li Y, Sommerfeld M, Hu Q, Xu J. Molecular mechanisms for photosynthetic carbon partitioning into storage neutral lipids in Nannochloropsis oceanica under nitrogen-depletion conditions. Algal research. 2015;7:66-77.

44. Fan JS, Li YH. Maximizing the yield of nanocrystalline cellulose from cotton pulp fiber. Carbohydrate polymers. 2012;88(4):1184-8.

45. Liu ZY, Wang GC, Zhou BC. Effect of iron on growth and lipid accumulation in Chlorella vulgaris. Bioresour Technol. 2008;99(11):4717-22.

\section{Figures}



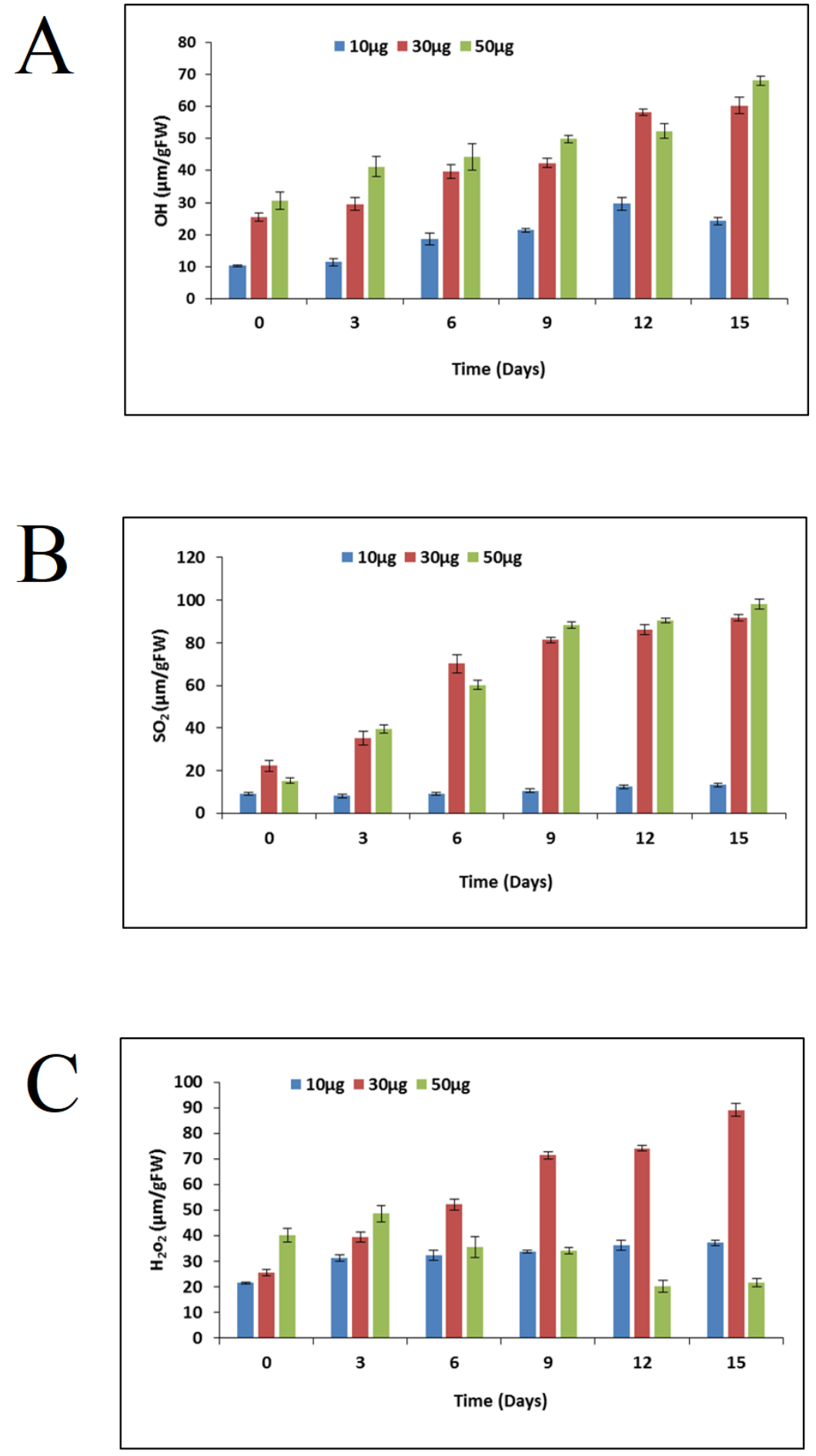

\section{Figure 1}

a Effect of different concentration of standard siderophore on hydroxyl radicals $(\mathrm{OH})$ contents in $\mathrm{C}$. variabilis. Values are presented as the mean \pm standard deviation $(n=3)$. Values with the different letters represent a significant difference $(P<0.05)$ between treatments. $b$ Effect of different concentration of standard siderophore on superoxide radicals (02), contents in C.variabilis. Values are presented as the mean \pm standard deviation $(n=3)$. Values with the different letters represent a significant difference $(P<$ 
0.05) between treatments. $c$ Effect of different concentration of standard siderophore on hydrogen peroxide (H2O2), contents in C.variabilis. Values are presented as the mean \pm standard deviation $(n=3)$. Values with the different letters represent a significant difference $(P<0.05)$ between treatments.
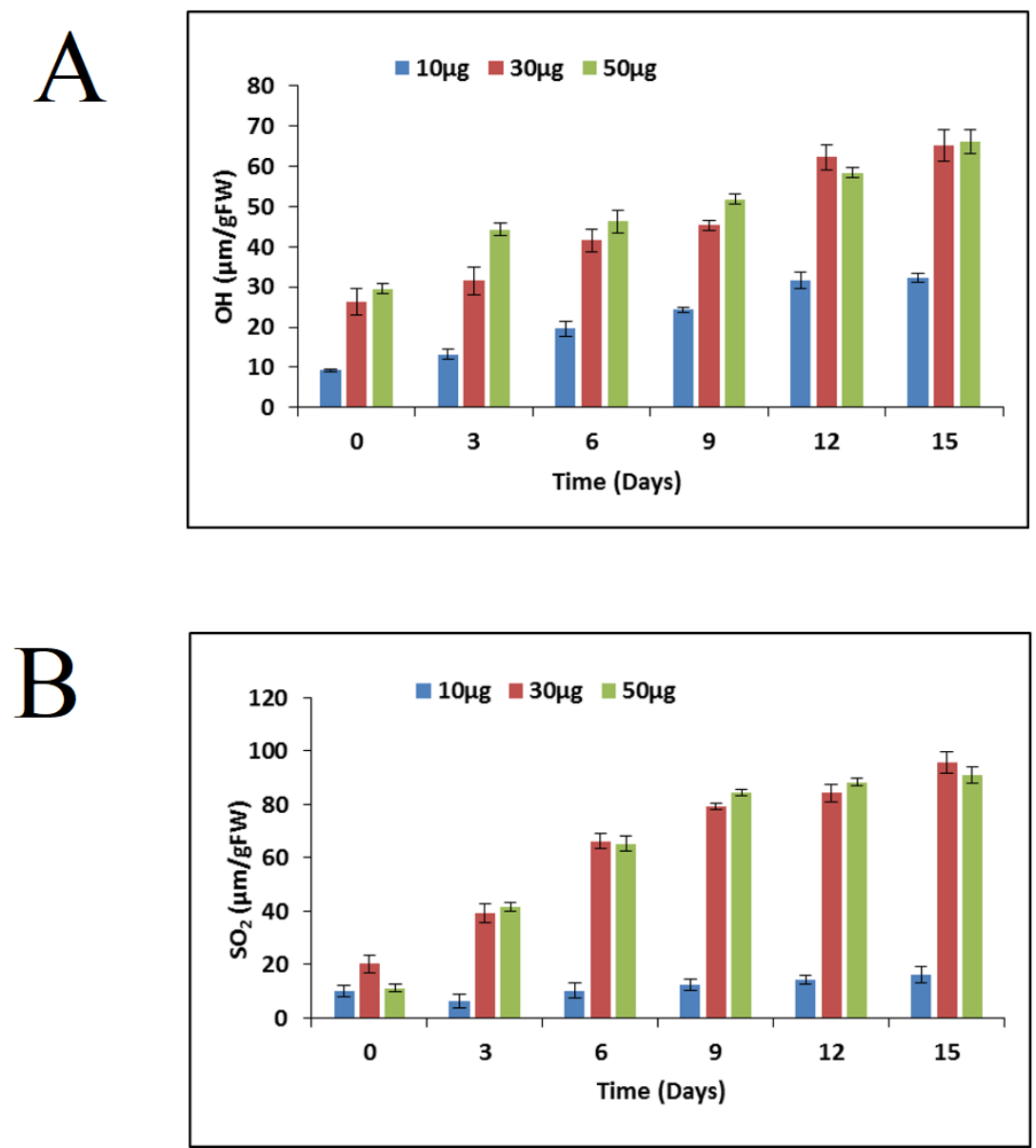

$\mathrm{C}$

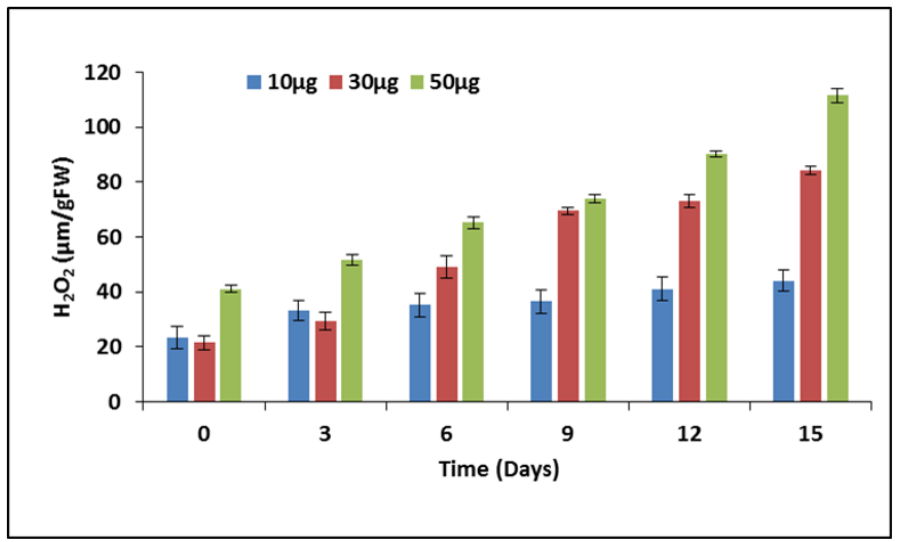

Figure 2

a Effect of different concentration of purified siderophore on hydroxyl radicals $(\mathrm{OH})$ contents in C.varibilis. Values are presented as the mean \pm standard deviation $(n=3)$. Values with the different letters 
represent a significant difference $(P<0.05)$ between treatments. $b$ Effect of different concentration of purified siderophore on superoxide radicals (02) contents in C.varibilis. Values are presented as the mean \pm standard deviation $(n=3)$. Values with the different letters represent a significant difference $(P<0.05)$ between treatments. $c$ Effect of different concentration of purified siderophore on hydrogen peroxide $(\mathrm{H} 2 \mathrm{O} 2)$ contents in C.varibilis. Values are presented as the mean \pm standard deviation $(n=3)$. Values with the different letters represent a significant difference $(P<0.05)$ between treatments.
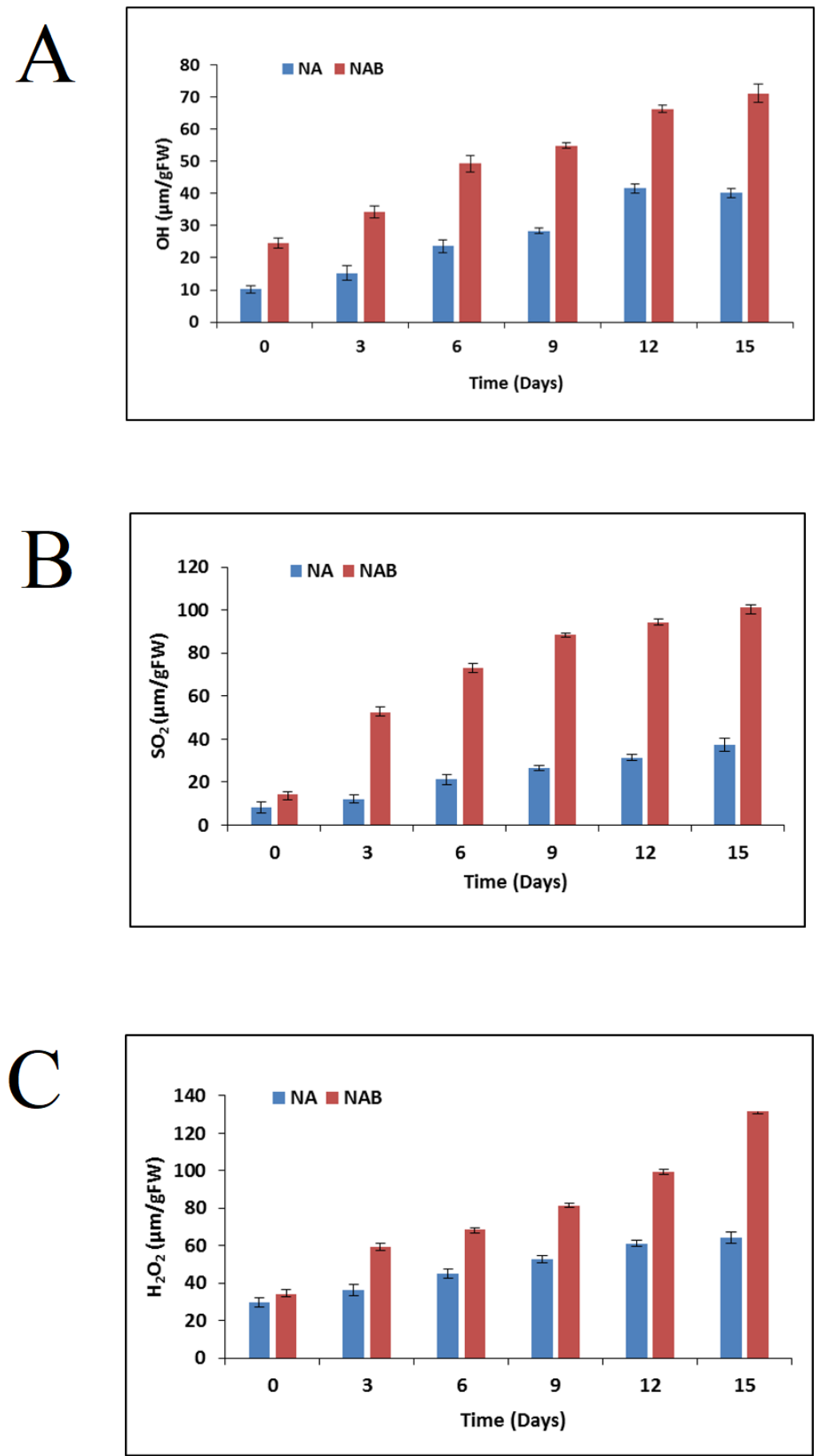

Figure 3 
a Effects of different concentration of axenic and co-cultured microalgae on hydroxyl radicals $(\mathrm{OH})$ contents in iron deficient conditions. Values are presented as the mean \pm standard deviation $(n=$ 3).Values with the different letters represent a significant difference $(P<0.05)$ between treatments. a Effects of different concentration of axenic and co-cultured microalgae on hydroxyl radicals $(\mathrm{OH})$ contents in iron deficient conditions. Values are presented as the mean \pm standard deviation $(n=$ 3).Values with the different letters represent a significant difference $(P<0.05)$ between treatments. $c$ Effects of different concentration of axenic and co-cultured microalgae on hydrogen peroxide $(\mathrm{H} 2 \mathrm{O} 2)$ contents in iron deficient conditions. Values are presented as the mean \pm standard deviation $(n=3)$. Values with the different letters represent a significant difference $(P<0.05)$ between treatments.

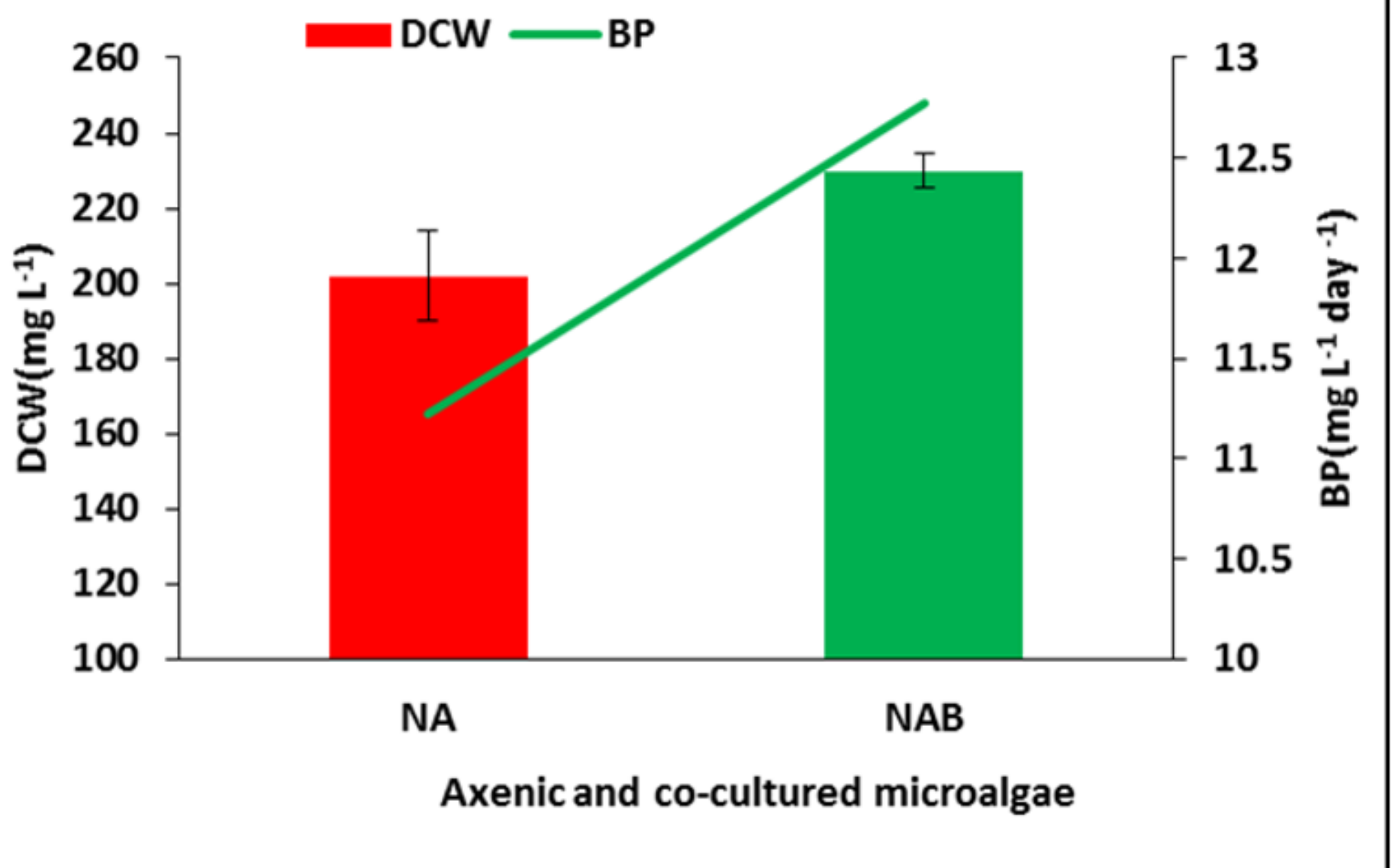

Figure 4

Effect on co-cultured on biomass productivity of microalgae. YA, YAB are axenic microalgae and cocultured microalgae with bacteria in the presence of iron. NA and NAB are axenic microalgae and cocultured microalgae with bacteria in the absence of iron (data represent mean \pm standard deviation of three replicates) 


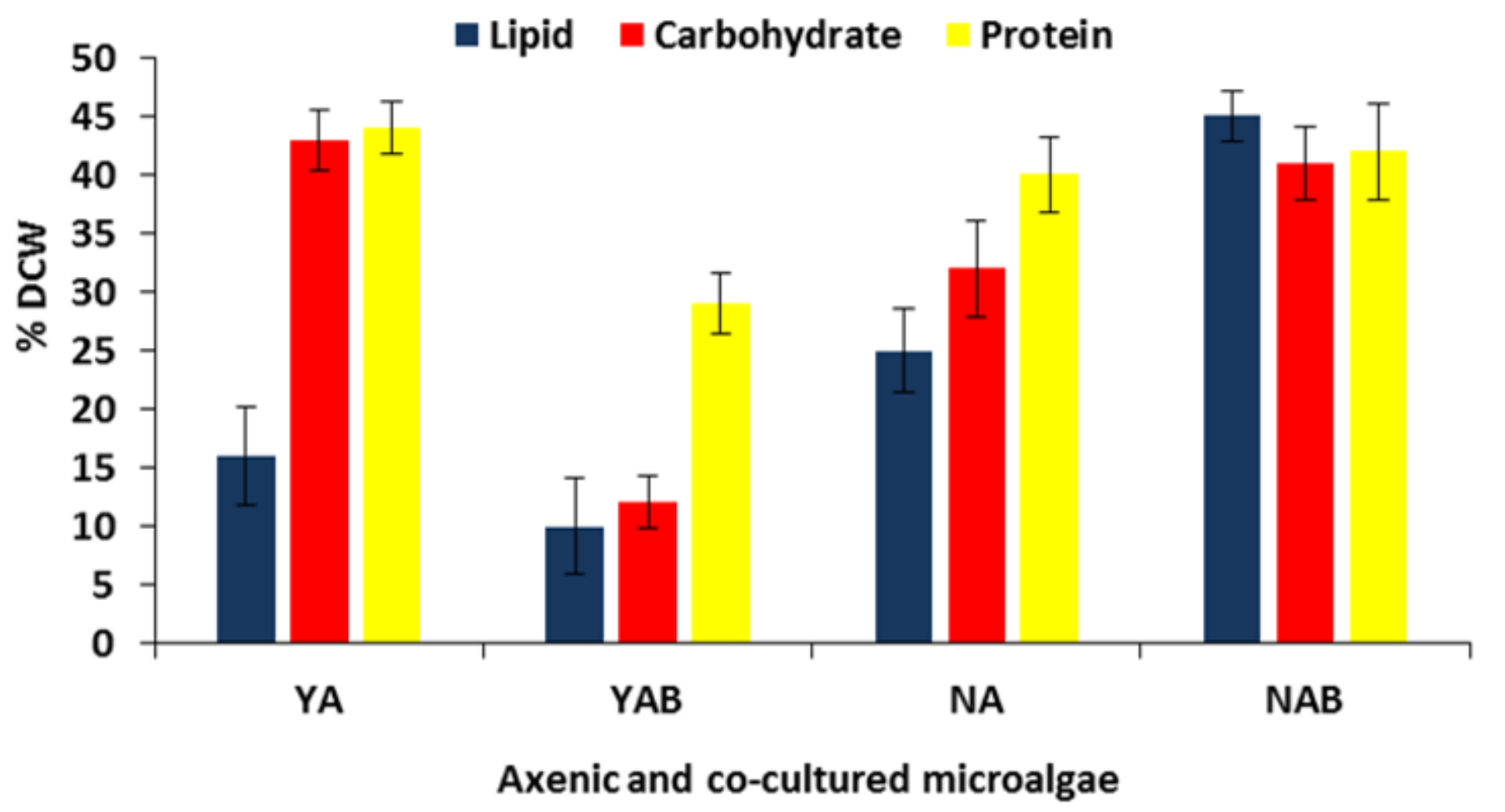

Figure 5

Effects of axenic and co-cultured C. variabilis on carbohydrate, lipid, and protein contents under iron sufficient and deficient conditions. YA and YAB are axenic microalgae and co-cultured microalgae with bacteria in the presence of iron. NA and NAB are axenic microalgae and co-cultured microalgae with bacteria in the absence of iron. Values are presented as the mean \pm standard deviation $(n=3)$. Values with the different letters represent a significant difference $(P<0.05)$ between treatments 


\section{YA}

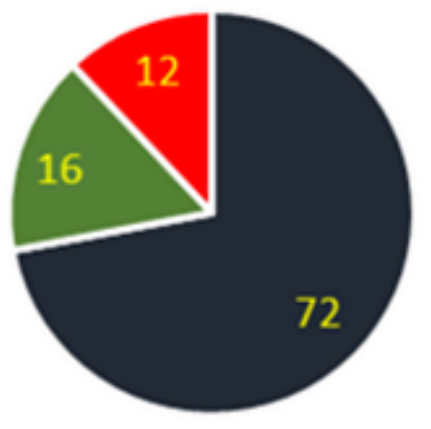

NA
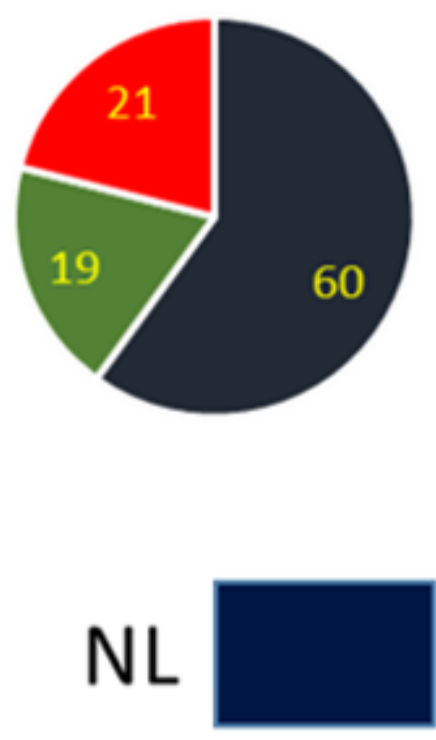

YAB

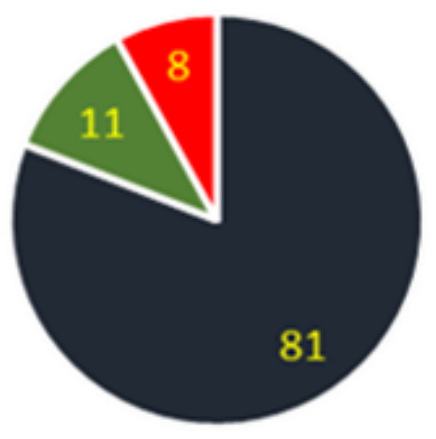

NAB

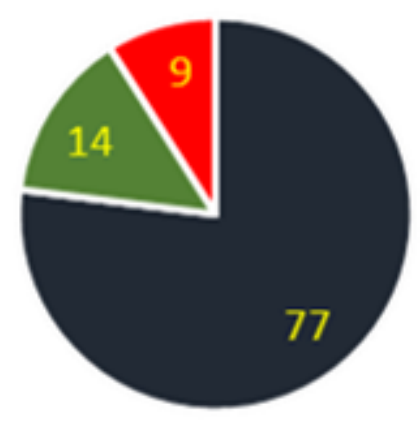

GL

$\mathrm{PL}$

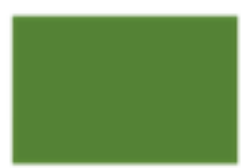

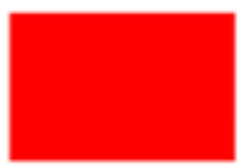

\section{Figure 6}

Variations in the lipid class composition of axenic and co-cultured microalgae under iron sufficient and deficient conditions under nitrogen deficiency. Phospholipids (PL), neutral lipids (NL), and glycolipids $(G L)$. Values are presented as the mean \pm standard deviation $(n=3)$. Values with the different letters represent a significant difference $(P<0.05)$ between treatments.

\section{Supplementary Files}


This is a list of supplementary files associated with this preprint. Click to download.

- GraphicalAbstract.jpg 